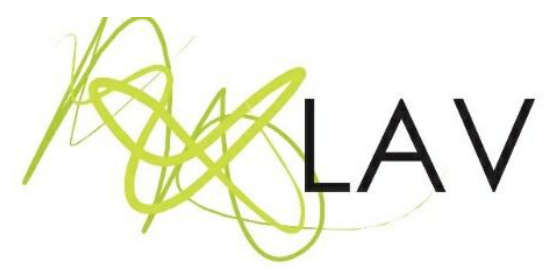

\title{
A abordagem da cognição imaginativa e a teoria do desenvolvimento da capacidade criadora infantil: relações teóricas entre Efland e Lowenfeld acerca do processo de construção do desenho infantil
}

The imaginative cognition approach and the theory of children's creative capacity development: theoretical relationships between Efland and Lowenfeld about the construction process of children's drawing

Kécia Maria Alencar de Souza Instituto Federal de Educação, Ciência e Tecnologia do Ceará

José Maximiano Arruda Ximenes de Limaii Instituto Federal de Educação, Ciência e Tecnologia do Ceará

\section{Resumo}

O presente artigo tem como objetivo analisar a abordagem da cognição imaginativa, de Arthur Efland, e a teoria do desenvolvimento da capacidade criadora, de Viktor Lowenfeld, estabelecendo as contribuições dessas abordagens e a correlação entre elas, no que concerne ao estudo da capacidade criadora infantil por meio de desenhos. Para tal, ressalta-se que Arthur Efland ([2002] 2004) sugere uma abordagem baseada na imaginação, que utiliza metáforas e experiências de narrativas como recursos para comprovar que a imaginação é uma atividade de desenvolvimento cognitivo bem estruturada. Focaliza-se, também, as contribuições teóricas de Viktor Lowenfeld ([1947] 1977) acerca do desenvolvimento do desenho infantil por meio de etapas de acordo com as idades das crianças. Conclui-se que ambas teorias embasam a criação infantil, oportunizando o aparecimento de experiências com desenhos que trabalham a imaginação, a autonomia, a criatividade e o respeito à individualidade, consequentemente, favorecem o desenvolvimento integral das crianças.

Palavras-chaves: cognição imaginativa, desenho infantil, metáforas, experiências de narrativas.

Enviado em: 26/02/21 - Aprovado em: 09/06/21

\begin{abstract}
This article aims at analyzing Arthur Efland's approach to imaginative cognition and Viktor Lowenfeld's theory of creative capacity development, establishing the contributions of these approaches and their correlation, focusing on the study of the development of the child creative process through graphics. To reach this goal, we emphasize that Arthur Efland (2004) suggests an approach based on imagination, which uses metaphors and narrative experiences as resources to prove that imagination is a well-structured cognitive development activity. We also show the theoretical contributions of Viktor Lowenfeld (1977) where, he explains, the development of children's drawing through stages according to the children's ages. We conclude that both theories are the foundation of
\end{abstract}


children's creation, providing opportunities for the emergence of experiences with drawings that work on imagination, autonomy, creativity and respect for individuality, consequently, favoring the integral development of children.

Keywords: Imaginative cognition, children's drawing, metaphors, narrative experiences.

\section{As abordagens teóricas da cognição imaginativa e do desenvolvimento da capacidade criadora}

Arthur Efland ([2002] 2004) retrata a abordagem da Cognição Imaginativa, explicitando que a imaginação é uma atividade superior bem estruturada de desenvolvimento cognitivo. Nessa atividade, na concepção do autor, utiliza-se as metáforas cognitivas e as experiências de narrativas como recursos superiores que usam a subjetividade das Artes como uma maneira de expressar algo que não pode ser expressado em palavras. Ou seja, as metáforas e as experiências de narrativas estabelecem novos significados, por meio da imaginação que é importante para a nossa capacidade cognitiva, a qual estabelece associações significativas. Efland, com relação a essa abordagem, relata e sugere contribuições a estudos de vários teóricos que aprofundaram as questões do desenvolvimento cognitivo, anteriores às suas investigações.

Lowenfeld ([1947] 1977), por sua vez, explica o desenvolvimento do desenho infantil por meio de etapas de acordo com as idades das crianças, quais sejam: fase das garatujas ( 2 a 4 anos), fase pré-esquemática ( 4 a 7 anos), fase esquemática ( 7 a 9 anos) e a fase do realismo (9 a 12 anos), estendendo-as à adolescência também, como: fase pseudonaturalista (12 a 14 anos) e fase da decisão (14 a 17 anos). Essas divisões em fases mostram pequena similaridade com as teorias de desenvolvimento cognitivo de Piaget, mas somente são iguais na questão de dividirem as etapas baseadas por idades das crianças, uma vez que Lowenfeld retrata o desenvolvimento da capacidade criadora, focando algumas expressões artísticas, principalmente o desenho. Efland (2004) faz referência aos estudos e pesquisas de Lowenfeld:

Lowenfeld no sólo identifico diversos estadios de desarrollo en la habilidade dibujar, sino que su texto proporciona guías a los docentes basadas en estas mismas características. Mientras la descripción que hace Lowenfeld del desarrollo puede describirse como una teoría de estadios basados en la edad, es importante no equiparar su trabajo con el Piaget, a pesar de que ambos se basen en los estadios para dar cuenta de los avances en el desarrollo. Lowenfeld se tomaba el aspecto emocional del desarrollo mucho más en serio que Piaget, cuyas investigaciones se centraban en las operaciones implicadas en la cognición, es decir, el pensamiento lógico-científico (EFLAND, 2004, p. 68-69). 
A abordagem da cognição imaginativa e a teoria do desenvolvimento da capacidade criadora infantil: relações teóricas entre Efland e Lowenfeld acerca do processo de construção do desenho infantil

Efland (2004) faz uma comparação entre os estudos de Piaget e de Lowenfeld, deixando claro que Lowenfeld considerava aspectos emocionais no desenvolvimento do desenho infantil, enquanto Piaget elegia como mais importante os pensamentos lógicos científicos.

No presente artigo, nossa intenção é analisar a abordagem da cognição imaginativa de Artur Efland, bem como a teoria do desenvolvimento da capacidade criadora de Viktor Lowenfeld, focando, mais atentamente, no desenvolvimento do desenho infantil. Analisaremos e correlacionaremos as contribuições dessas duas abordagens, buscando elucidar as expressões artísticas infantis por meio da evolução dos desenhos que são estudados na teoria da capacidade criadora infantil, possibilitando os desvendamentos do desenvolvimento cognitivo, afetivo e social das crianças em suas manifestações criadoras. Este artigo é um estudo bibliográfico, de cunho hermenêutico, pois é resultado de estudos, análises e interpretações sobre o desenvolvimento do desenho infantil e a sua correlação com a imaginação e o processo cognitivo envolvido. Buscamos embasamento teórico nas obras seguintes obras: Arte y cognición: La integración de las artes visuales en el currículum (2004), de Artur Efland, e Desenvolvimento da capacidade criadora (1977), de Viktor Lowenfeld.

\section{Cognição Imaginativa}

De acordo com Efland (2004), a imaginação sempre foi excluída das teorias cognitivas. Considerando a necessidade de estudos que comprovassem o potencial cognitivo da imaginação na educação, o autor explora possibilidades de desenvolver conhecimento, entendimento e aprendizagem, identificando um espaço para as artes visuais, nas práticas pedagógicas, a partir da perspectiva de imaginação.

Para Efland (2004), o conceito de imaginação se baseia na ação ou no poder de formar imagens mentais do que realmente não está presente para os nossos sentidos ou o que não foi experimentado. De acordo com o autor, é também a ação ou poder de criar novas ideias e/ou imagens por meio da combinação e reorganização de experiências anteriores. Além disso, Efland (2004), define o conceito de cognição imaginativa como o processo cognitivo que permite aos indivíduos organizar ou reorganizar imagens, combinar ou recombinar símbolos, como na criação de metáforas ou nas produções de narrativas, resultando em produtos da imaginação diferentes do pensamento comum, todos os dias, por ser mais inovador e menos preocupado por comunicação típica ou convencional. Efland ainda afirma que o conceito de cognição imaginativa não é a operação cognitiva específica por si só, mas é o resultado de ações cognitivas que permitem aos indivíduos construir 
significados e eles geralmente dependem menos das maneiras de pensamento e comunicação convencional, governada por regras, ou proposicional.

Contextualizando esse conceito à Educação Infantil, notamos que a cognição imaginativa pode ocorrer quando favorecemos algumas práticas pedagógicas, como contações de histórias e produções de desenhos infantis. Nessas, as crianças desenham e utilizam as metáforas visuais para explicar algo que não conseguem expressar em palavras e utilizam também as experiências de narrativas nos desenhos para demonstrar sequência de fatos e acontecimentos das histórias contadas na sala ou histórias do seu contexto de vida, baseadas na realidade que vivem e com quem convivem ou que gostariam ou imaginam vivenciar.

Muitos estudos e pesquisas sobre o processo de ensino e aprendizagem têm como público as crianças do Ensino Fundamental e os adolescentes do Ensino Médio. No caso da Educação Infantil, seu direito, sua história, suas lutas e seus estudos da arte-educação são recentes, logo, há inúmeros desafios a serem refletidos e estudados, uma vez que as crianças têm a natureza potente e criativa, e são capazes de criar, construir assuntos, relacionar temas, elencar memórias das suas experiências e vivências passadas do contexto de vida delas ou até de conhecimentos já adquiridos, por meio de várias expressões artísticas. Ademais, as crianças são aptas a sentir, entender, interpretar, analisar e criticar obras de artes de artistas, ou seja, se os adultos que a circundam são sensíveis a essas potências, eles irão favorecer e facilitar esse processo de descobertas e aprendizagens.

Efland (2004) relata que a aprendizagem das crianças da primeira infância se fundamenta mais no trabalho com os sentidos e com uso de objetos concretos. Desse modo, o currículo da Educação Infantil poderia favorecer uma aprendizagem que desenvolvesse cognitivamente as crianças, respeitando os limites das formas de pensamento e o desenvolvimento intelectual do estágio que as crianças se encontram. Por meio das experiências da Educação Infantil, é percebido que as crianças são estimuladas sensorialmente, por intermédio do trabalho com os cinco sentidos, mas que também são capazes de criarem abstrações nas suas produções, utilizando as suas estruturas de conhecimento e os seus saberes prévios.

Efland (2004) utilizou, em suas investigações, várias abordagens de estudos e pesquisas sobre a imaginação, mas utilizamos especificamente a abordagem baseada na cognição imaginativa, na educação infantil, focalizando os desenhos infantis. Conforme o trabalho linguístico de dois estudiosos e pesquisadores chamados George Lakoff e Mark Johnson, Efland (2004) afirma que:

$[u] n$ tecer enfoque al estudio de la imaginación está basado en el 
trabajo lingüístico de George Lakoff, quien, junto a Mark Johnson (1980) estudió los fundamentos cognitivos de actividades mentales aparentemente abstractas, como la categorización y la metáfora, según se observaban en los estudios empíricos del comportamiento linguístico. Afirman que hay un creciente cuerpo de evidencia sobre la existencia de lo que ellos denominan "un nivel de operaciones cognitivas de imagen-esquemático". Como los esquemas de Piaget, estos existen en un nivel de generalidad y abstracción que les permite servir de forma repetida como patrones de identificación en una variedad de actividades cognitivas estructuradas similarmente de modos pertinentes (JOHNSON, 1987) (EFLAND, 2004, p. 188).

De acordo com Efland (2004), George Lakoff e Mark Johnson basearam suas pesquisas nos fundamentos cognitivos das atividades mentais abstratas, como a categorização e a metáfora. Nesses estudos, podemos constatar que as crianças da Educação Infantil também são capazes de ter operações cognitivas superiores com abstrações por meio do uso de metáforas e experiências de narrativas, representadas por suas criações de desenhos em que utilizam suas autonomias e imaginações.

Para melhor entendimento da cognição imaginativa, explicitamos alguns tópicos que são abordados, desenvolvidos e refletidos pela abordagem, como Metáforas e Estruturas de narrativas, contextualizando para a realidade da Educação Infantil e respeitando os níveis de desenvolvimento das crianças.

\section{Metáforas}

Segundo Efland (2004):

[l]a metáfora es un componente esencial de la imaginación en formas de la cognición tales como la razón abstracta, esto tiene implicaciones inequívocas también para el arte. Las artes son lugares en que los saltos metafóricos de la imaginación se precian por su potencial y excelencia estética. Es más, en el arte es donde la experiência, la natureza, y la estructura de la metáfora se convierten en el principal objeto de estudio. Esto ocorre en actividades en que los individuos crean obras de arte, pero también entra en juego en la interpretación de obras de arte. Profundizar la fuente de la imaginación y el papel que puede jugar en la creación de significado personal, y en la transmisión de la cultura pasa a ser la razón de ser y el objetivo de introducir el arte en la educación (EFLAND, 2004, p. 206).

A partir dessa fala de Efland, incluímos esse conceito de metáfora também para as crianças, pois elas são capazes também de entender metáforas, utilizá-las em suas linguagens, em seus desenhos e em seus pensamentos. Efland (2004), além disso, comenta que Lakoff (1987) fez uma teoria de significado, a qual utiliza a metáfora como recurso de conexão entre os esquemas das experiências corporais com as imagens 
esquemáticas. Para Efland,

[I]a principal afirmación de Lakoff y Johnson es que las imágenesesquemas, que emergen de sensaciones y percepciones: corporales, alcanzan los ámbitos mental, epistémico o lógico de la cognición, lo que hace que los actos de cognición como la categorización y la metáfora sean posibles. Aquello a lo que normalmente nos referimos como pensamiento de orden superior, las comprensiones más amplias que denominamos razón abstracta e incorpórea, tiene sus inicios con la formación de imágenes-esquemas en la experiencia corporal (EFLAND, 2004, p. 201)

As crianças estão em pleno desenvolvimento motor e as suas experiências e vivências de aprendizagem são baseadas em ações corporais, como brincar, dançar, etc. A teoria de significado que Lakoff desenvolveu se enquadra, também, às crianças, porque, por meio de sensações e percepções sobre ações corpóreas, elas são capazes de ter pensamentos de ordem abstrata, ou de ordem superior, gerando o desenvolvimento cognitivo, por intermédio de categorizações e metáforas, respeitando as limitações e as etapas de desenvolvimento de cada criança. É relevante mencionar que essas etapas não seguem somente a classificação etária, pois variam de criança a criança, em íntima relação com suas experiências pessoais, socializações, vivências, memórias e realidades, bem como com estímulos recebidos para desenvolver a criatividade e a autonomia. Desse modo, as produções e criações favorecem o desenvolvimento cognitivo, por meio de desenhos e de outras expressões artísticas que os professores/adultos devem estimular e mediar. Como exemplo disso podemos citar a modelagem que dá a oportunidade da criança sair do plano bidimensional do desenho para criar no plano tridimensional, também através de pinturas, colagens, confecção de isogravuras, ou mesmo construir com materiais naturais e/ou não estruturados, tais como os reciclados.

Efland (2004) continua a citar as pesquisas de Lakoff, quando relata o conceito contextualizado de categorização e metáfora, desenvolvido por este.

Lo que Lakoff (1987) está diciendo es que los esquemas que emergen de nuestra experiencia corporal tienen una lógica básica que les permite formar conexiones de, al menos, dos formas: en primer lugar, las cosas que se parecen de certo modo pueden agruparse en categorías; y en segundo lugar, las cosas que aparentemente son diferentes pueden unirse y tener significado a través de la metáfora. "Lo que se ha denominado razón abstracta tiene una base corporal en nuestro funcionamiento físico cotidiano" (p. 278). De hecho, la teoría del significado y la racionalidad de Lakoff y Johnson puede enraizarse en aspectos del funcionamiento corporal. (EFLAND, 2004, p. 200-201).

Efland relata que Lakoff (1987) defende a ideia de que os esquemas que resultam da nossa experiência corporal tem uma lógica que permite formar conexões, agrupandose em categorias de coisas iguais ou diferentes; para facilitar a compreensão e conseguir 
A abordagem da cognição imaginativa e a teoria do desenvolvimento da capacidade criadora infantil: relações teóricas entre Efland e Lowenfeld acerca do processo de construção do desenho infantil

representar, utilizam-se da metáfora. As crianças são altamente corpóreas e o desenvolvimento cognitivo delas, muitas vezes, está ligado ao desenvolvimento motor, por isso elas dialogam, pensam e desenham, quase sempre se movimentando. Para tornar isso mais claro, citamos alguns exemplos: quando contamos uma história, a criança escuta e faz as ações do personagem, movimentando seu corpo; o mesmo ocorre na situação inversa, em que contam e tentam demonstrar, com movimentos, o que acontece com personagens, objetos e paisagens. Quando desenham, também representam com o corpo, tanto durante o processo, quanto na socialização.

Efland (2004) relata, em vários pontos do seu livro Arte y cognición, a importância das artes para o desenvolvimento cognitivo e que a metáfora é uma expressão desse desenvolvimento. Nessa perspectiva, reiteramos a importância das crianças desenvolverem suas capacidades criadoras a partir de incentivo e motivação, principalmente por meio de orientações e estímulos dos pais e professores/adultos. Efland (2004) descreve a importância das metáforas para a área das artes:

Las metáforas establecen conexiones entre objetos y eventos que aparentemente no están relacionados, aunque, en el ejemplo de que acabamos de mencionar 'más- está-arriba', que acabamos de citar, la fuente y el objetivo están tan cercanos que actúan como discurso porposicional cotidiano en lugar de lo que normalmente consideramos que es verdaderamente metafórico. Encontramos metáforas en todos los campos de estudio, incluidas las artes. Las artes no tienen el monopolio de las metáforas pero, como veremos, pueden reclamar una atribución especial respecto al tema de la metáfora, a saber, que las artes son lugares en que el artista y el espectador son conscientes de lo que es metafórico en una expresión determinada. En otros ámbitos, el uso de la metáfora probablemente quedará en el foco (EFLAND, 2004, p. 201).

Efland explica que as metáforas estabelecem conexões entre objetos e acontecimentos que aparentemente não estão relacionados. Entendemos que muitos assuntos e coisas que não conseguimos explicar ou representar são retratados de uma forma compreensível por meio das metáforas. As crianças, por sua vez, utilizam metáforas visuais nos seus desenhos por meio da vontade de registrar sentimentos, emoções, entre outras questões, a exemplo de quando desenham algo para suas mães (utilizam corações e outros elementos para representar o amor que sentem por elas).

\section{Experiências de narrativas}

As pessoas já nascem em experiências de narrativas, vivenciam histórias próprias, com uma sequência e cronologia. Do mesmo modo é a elaboração do pensamento das crianças, porque são cercadas de histórias que as tornam narradoras das suas próprias 
histórias de vidas. Esse conjunto de histórias ouvido na infância interage com nossas experiências, constituindo a nossa formação narrativa. Na escola, outro tipo de experiência de narrativa é a contação de histórias - esse tipo de experiência dá a oportunidade de utilizar a criatividade e a imaginação, bem como de criar personagens e mudar a narrativa. Por exemplo, uma criança que não gostou do final de determinada história, baseada em sua imaginação e experiência de vida, pode modificá-lo, desenvolvendo seu senso crítico e sua criatividade pensada e refletida. Isso é muito observado nos desenhos das crianças que utilizam esse tipo de expressão artística para atuarem ou se expressarem no mundo em que vivem.

Efland (2004) retrata a opinião de Johnson (1987) sobre as experiências de narrativas no contexto cotidiano das pessoas:

Cuando se trata de explicar cómo los humanos dan sentido al mundo, escribe Johnson: "debe existir un lugar central para la noción de unidad narrativa. No sólo nacemos en narrativas complejas y comunes, también experimentamos, comprendemos y organizamos nuestras vidas como historias que estamos viviendo" (JOHNSON, 1987, p. 171-172) (EFLAND, 2004, p. 205).

As experiências de narrativas fazem parte de todo o desenvolvimento humano, pois já nascemos fazendo parte de uma história, de uma narrativa. Na Educação Infantil, é muito importante propiciar espaços às experiências de narrativas, porque cada criança traz experiências de vida do contexto em que está inserida. Nos desenhos, as crianças representam as histórias em que vivem, representam histórias que querem viver, misturam as fantasias dos contos de fadas com as suas vidas, utilizando a imaginação, etc.

De acordo com nossos estudos, defendemos que a cognição imaginativa na educação infantil pode ser possível. Segundo Efland (2004), o principal propósito educativo devia ser o desenvolvimento cognitivo dos estudantes, então, incluímos as crianças, por acreditarmos que são seres humanos em constante desenvolvimento cognitivo, afetivo e social. Efland (2004) relata que:

El objetivo final de la educación debería ser la maximización del potencial cognitivo de los estudiantes. Esto requiere el reconocimiento del reino de la imaginación y las las herramientas cognitivas, como la categorización y la metáfora, que hacen posible esta operación; seguramente en todas las materias, pero de forma fundamental en las artes visuales (EFLAND, 2004, p. 209- 210).

Com esse trecho final, voltamos a dar importância a Educação Infantil, composta por crianças que estão em pleno desenvolvimento cognitivo e que são inundadas por experiências nos seus cotidianos, o que consideramos uma fase muito importante para começar a aplicar a abordagem da cognição imaginativa, respeitando os níveis de desenvolvimento de cada criança e possibilitando a formação e o desenvolvimento de 
A abordagem da cognição imaginativa e a teoria do desenvolvimento da capacidade criadora infantil: relações teóricas entre Efland e Lowenfeld acerca do processo de construção do desenho infantil

futuros adolescentes e adultos pensantes e críticos, capazes de atuar no mundo à sua volta de forma transformadora e humanitária.

\section{O desenvolvimento do desenho infantil na visão de Viktor Lowenfeld}

Lowenfeld (1977) desenvolveu pesquisas e estudos relacionados ao desenvolvimento da capacidade criadora das crianças, incluindo uma investigação aprofundada do desenvolvimento do desenho infantil, em que estipula fases de acordo com as idades das crianças: fase das garatujas ( 2 a 4 anos), fase pré-esquemática (4 a 7 anos), fase esquemática ( 7 a 9 anos) e fase do realismo (9 a 12 anos). Lowenfeld (1977) também classificou em etapas a fase da adolescência: fase pseudonaturalista (12 a 14 anos) e fase da decisão (14 a 17 anos).

O autor caracteriza o desenvolvimento da capacidade criadora infantil, tendo como base principal as expressões artísticas das crianças e como referência, principalmente, o desenho infantil. Lowenfeld (1977) retrata a opinião de Bettelheim, sobre a dependência da criança que apoia seu desenvolvimento e aprendizado a outras pessoas, tendo uma postura de imitação das ideias de um adulto ou de um parceiro mais independente, tornando-se uma criança sem autonomia. A criança que espera direcionamentos para expressar-se não dá lugar à criação das suas próprias ideias e reflexões e se torna dependente de adultos, ao não considerar suas próprias experiências. Em decorrência disso, torna-se insegura e pode desenvolver distúrbios psicológicos e emocionais futuramente. Essas consequências afetam a formação da personalidade de crianças, adolescentes e adultos, os quais podem ter dificuldades em transformar e modificar suas realidades, as quais são, muitas vezes, desafiadoras por si só.

A criança que se expressa de acordo com seu nível é encorajada em seu próprio pensamento independente e exprime suas idéias, suas reflexões, por seus próprios meios. A criança que imita pode tornarse dependente no raciocínio e subordinar suas idéias e a expressão destas às de outrem. Se a criança que imita não pode dar expressão às suas reflexões, sua dependência dos outros pode levá-la ao malogro. A criança inibida, contraída, mais acostumada à imitação do que à auto-expressão, apóia-se nos pais, nos professores ou nos companheiros, para receber orientação. A arte, através da auto expressão, pode desenvolver o eu como importante ingrediente da experiência. Como quase todos os distúrbios emocionais ou mentais estão vinculados à falta de autoconfiança, é fácil perceber como a estimulação adequada da capacidade criadora da criança pode fornecer salvaguarda contra tais distúrbios (BETTELHEIM, 1950) (LOWENFELD, 1977, p. 30).

São necessários estímulos adequados para favorecer o desenvolvimento da capacidade criadora das crianças, fornecendo os meios necessários para expressarem suas 
ideias, suas opiniões, seus pontos de vista, utilizando suas autonomias, seus conhecimentos prévios e suas imaginações, em criações diversas. As crianças devem ser respeitadas, pois cada uma tem suas características de personalidade. Algumas crianças podem ser tímidas e introvertidas, enquanto outras mais comunicativas e extrovertidas. Dessa forma, precisamos respeitar a individualidade de cada uma e possibilitar que se desenvolvam integralmente.

Em relação à arte como meio de compreender e estimular os desenvolvimentos específicos das crianças (emocional, intelectual, físico, perceptual, social, estético e criador), Lowenfeld (1977) retrata a importância de cada tipo, analisando-os individualmente. Todos esses desenvolvimentos podem e devem ser trabalhados para a formação integral da criança. A arte, de modo geral, proporciona o desenvolvimento integral, utilizando vários meios e recursos, como o desenho infantil.

Sobre os desenhos, Lowenfeld (1977) relata que eles

proporcionam boa indicação sobre o desenvolvimento da criança, o qual se desenrola desde um ponto de vista egocêntrico até uma gradual conscientização do eu, como parte de um ambiente mais vasto. Até os rabiscos indefinidos de uma criança, na fase das garatujas, podem representar, na realidade, um sentimento ou os sentimentos do eu. Possivelmente, o primeiro símbolo humano não é um homem, em absoluto, mas uma representação do eu que lentamente começa a adquirir forma no discernimento de qualquer pessoa (LOWENFELD, 1977, p. 60).

É de elevada importância não categorizar e tornar fixas as possibilidades de desenhos como intenções marcadas por características únicas e possíveis de reprodução intuitiva, pois a imaginação, a autonomia e a liberdade do processo de desenvolvimento criador devem ser livres e respeitadas nas suas várias manifestações artísticas, especialmente no que é natural das possibilidades expressivas, como a representação das experiências significativas, as quais são de valor importantíssimo e imensurável no desenrolar dos desenvolvimentos humanos.

Relatando e explicando o desenvolvimento do desenho infantil, por intermédio da teoria e classificação de Lowenfeld (1977) discorreremos nossos estudos na fase préesquemática (4 a 7 anos) do desenvolvimento do desenho infantil de Lowenfeld. Como Lowenfeld comenta, o desenho infantil pode não ter significado para os adultos, mas para as crianças tem a sua significação. Assim, o adulto não deve questionar esse desenho ou intervir para modificá-lo, mas sim apoiar e incentivar as crianças a desenvolverem cada vez mais seus desenhos com confiança em si, pois estes são reflexos do desenvolvimento cognitivo, afetivo, motor e social.

A fase pré-esquemática do desenvolvimento do desenho infantil de Lowenfeld 
A abordagem da cognição imaginativa e a teoria do desenvolvimento da capacidade criadora infantil: relações teóricas entre Efland e Lowenfeld acerca do processo de construção do desenho infantil

(1977) é a etapa a ser estudada neste tópico, pois abrange a idade que escolhemos como recorte para analisarmos de acordo com pesquisas mais detalhadas. A partir disso, teremos um embasamento teórico mais profundo para facilitar os entendimentos e as análises, bem como para entendermos os possíveis desenvolvimentos intelectuais, sociais e afetivos das crianças, utilizando o desenho infantil como recurso. Essa fase é muito importante para o desenvolvimento do desenho das crianças, pois, geralmente, elas executam as suas primeiras tentativas de representação real de sentimentos, emoções e experiências que seu meio e contexto de vida possibilitam. Ademais, contempla a ampliação dessas experiências com o aumento do repertório de conhecimento e com o surgimento de novas aprendizagens, o que favorece e possibilita experiências mais significativas para a vida das crianças.

É de grande importância que os professores entendam, possibilitem e valorizem o desenho infantil para o desenvolvimento e aprendizagem das crianças. Por vezes, ainda os professores apresentam dificuldades em trabalhar com desenho de forma significativa, respeitando as experiências e os conhecimentos prévios das crianças. Lowenfeld (1977) já criticava o fato de os educadores não respeitarem o desenvolvimento das crianças, tentando alfabetizá-las antes do tempo, utilizando as artes para tal ou como meio para passar algum conhecimento, como o matemático, sem respeitar o desenvolvimento cognitivo das crianças. Lowenfeld (1977) expõe que

[e]nquanto a criança estiver na fase pré-esquemática, não haverá vantagem alguma em tentar ensiná-la a ler (SIBLEY, 1957) ou em procurar fazê-la raciocinar, de modo abstrato, sobre as relações lógicas dos números. Embora as crianças possam aprender cedo a contar (PENTZ, 1965) ou a reconhecer palavras, não há compreensão genuína do conteúdo.

Desde que as experiências com o próprio eu, como parte do meio, são um dos pressupostos mais importantes para a cooperação e a coordenação visual, a incapacidade da criança para relacionar as coisas entre si no espaço, em seus desenhos, é uma clara indicação de que ainda não amadureceu para cooperar socialmente e de que ainda não possui aptidão necessária para relacionar, mutuamente, as letras ou para aprender a ler. Uma professora de jardim de infância pode facilmente depreender, dos desenhos de uma criança, se ela está apta a participar das obras que exijam coordenação espacial. Forçar a criança a realizar, prematuramente, tarefas para as quais ainda não está apta pode levá-la a ações e atitudes indesejáveis, que talvez durem mais tempo e sejam mais importantes, em última instância, do que a realização da tarefa, em determinado momento (LOWENFELD, 1977, p. 156).

A natureza da criança na fase pré-esquemática é egocêntrica; consequentemente, as suas vivências e experiências terão uma grande importância para o seu desenvolvimento integral, pois ela aprende de acordo com o meio que está a sua volta, 
tornando toda aprendizagem mais significativa para ela, se tiver relações diretas com o conhecimento contextualizado. Lowenfeld explana que,

[c]omo a criança se considera o centro de seu meio, na que poderíamos chamar fase de egocentrismo, as experiências que estão diretamente relacionadas com ela tornam-se mais significativas. A concepção que tem do seu mundo pode estar tão vinculada ao seu próprio eu que chegará até a confundir seus sentimentos e pensamentos com as coisas que a cercam. Se uma cadeira cai, fica preocupada com a possibilidade de a cadeira ficar ferida (PIAGET, 1960). E quase como se ela fosse a cadeira. Podemos afirmar, portanto, que a criança, nesta fase, está emocionalmente envolvida em suas relações espaciais. O tamanho dos objetos e os materiais que seleciona, do seu meio, e a maneira como eles são colocados, nesta fase inicial, estão condicionados, em grande parte, a juízos de valor. É evidente que o modo como a criança retrata o espaço está intimamente vinculado a todo o seu processo mental. Ensinar às crianças, desta idade, o conceito de espaço do adulto não só seria, para elas, extremamente confuso, como também poderia prejudicar a confiança infantil em seu próprio trabalho criador (LOWENFELD, 1977, p. 156).

O egocentrismo das crianças faz com que elas fiquem emocionalmente ligadas a suas relações espaciais e aos objetos que a cercam. Isso é representado também nos seus desenhos e nas suas brincadeiras, a exemplo de situações em que crianças se recusam a dividir os brinquedos com os colegas e ficam com eles a maior parte do tempo. Nesses casos, é necessária uma intervenção de um adulto mas, apesar disso, muitas crianças não se convencem a compartilhar os objetos.

O conhecimento prévio que as crianças trazem do contexto em que vivem tem que ser respeitado, valorizado e ampliado pelo educador, pois gera um desenvolvimento cognitivo, afetivo e social de grande significado. O mesmo vale para as diferenças individuais entre as crianças, pois cada uma é resultado das suas experiências pessoais. Elas trazem consigo muitos conhecimentos cotidianos que devem ser compartilhados, socializados e desenvolvidos nos meios em que convivem com os seus pares (coleguinhas e adultos). Lowenfeld (1977) retrata esse conhecimento prévio e as características individualizadas de cada criança:

As crianças diferem, enormemente, nessa idade. Cada uma é o produto de seus antecedentes familiares, de seu meio social e cultural, e assim como são tão diferentes os pais e o meio, assim também a própria criança varia. Portanto, os antecedentes desta não podem ser ignorados. Contudo, todas as crianças, nessa idade, tendem a ser, de modo geral, curiosas, plenas de entusiasmo, ávidas por iniciar tarefas, principalmente as que envolvam a manipulação de materiais, e ansiosas para expressar-se, embora não o façam de modo lógico. Aparentemente, a criança em idade pré-escolar desenvolve sua própria lógica, e, embora esteja ávida de interrogações, de 'porquês', parece ver o mundo tal como ele é, 
sem se aperceber de que também ela pode transformá-lo. O mundo gravita em torno dela, e sua experiência está limitada ao contato direto com o meio. A criança na fase pré-escolar brinca sozinha ou junto de outras crianças, e não com outras crianças; sua conversação é, muitas vezes, mais o reflexo do seu próprio pensamento do que a evolução de um dom social (LOWENFELD, 1977, p. 158-159, grifo no original).

De acordo com Lowenfeld (1977), as crianças da pré-escola veem o mundo de forma diferente dos adultos, com muita curiosidade, mas de modo egocêntrico; elas veem as coisas do mundo, mas sem a noção de que podem modificá-lo, até porque as crianças ainda estão conhecendo o meio que as cercam e suas linguagens.

Achamos que existem vários aspectos no desenho infantil que podem e devem ser investigados, os quais a teoria de Lowenfeld (1977) estuda, como a questão da percepção na fase pré-esquemática, que explicita que o modo como as coisas são representadas no desenho infantil é uma indicação das experiências que as crianças tiveram com essas coisas. Lowenfeld (1977) afirma que a

Percepção traduz mais do que simples conhecimento do aspecto visual dos objetos: inclui a conscientização de todos os sentidos, tais como as experiências sinestésicas ou auditivas. No momento em que a criança estabelece mais do que o mero significado de um objeto, começará a percepção visual e ela usará, então, outras linhas, além das simplesmente geométricas (LOWENFELD, 1977, p. 162-163).

Devido a isso, é necessário favorecer para as crianças experiências significativas, em que elas possam desenvolver vivências com os cinco sentidos (ver, ouvir, etc), em que sentirão e vivenciarão aquilo que estão aprendendo.

De acordo com Lowenfeld (1977), na fase pré-esquemática, na qual ocorrem as primeiras experiências representativas, devemos (educadores e pais) dar grande atenção e importância ao desenvolvimento da capacidade criadora das crianças. Essa etapa é essencial e decisiva para o desenvolvimento de várias linguagens das artes, pois as crianças estão em pleno desenvolvimento cognitivo, afetivo, social e motor. Desse modo, um ambiente propício e adequado à aprendizagem também ajuda a estimular o desenvolvimento da capacidade criadora, assim como educadores preparados para favorecer o desenvolvimento integral das crianças. Lowenfeld relata que

A atmosfera também é necessária às experiências artísticas. A forma como se diz alguma coisa a uma criança pode ser mais importante do que aquilo que Ihe é realmente dito. Num estudo realizado a respeito da influência do meio, de uma escola maternal, sobre os desenhos infantis (REICHENBERG-HACKETT, 1964), verificou-se que as crianças, numa atmosfera considerada de tolerância e apoio, faziam desenhos de nível superior aos das crianças num ambiente autoritário ou numa atmosfera de aissez-

Revista Digital do LAV - Santa Maria - vol. 14, n. 2, p. 42 - 67 - mai./ago. 2021 ISSN 1983 - 7348 
faire. Outros estudos tendem a corroborar estas conclusões; assim, a atitude do professor é decisiva para a experiência de aprendizagem. Quando o adulto manifesta interesse, proporciona atmosfera de apoio à atividade e age como se não houvesse nada mais importante, no mundo, que a experiência de desenhar, o ambiente está então preparado para a arte. Os dois outros extremos, o do professor que assume uma atitude passiva e não lhe importa o que a criança faça ou deixe de fazer, ou o do professor autoritário, que dita o que deve ser feito, parecem exercer influência negativa sobre o desenho e, portanto, sobre a própria personalidade infantil (LOWENFELD, 1977 , p. 165).

Há uma crítica nessa fala de Lowenfeld, em relação a professores autoritários que não respeitam as crianças como protagonistas das suas aprendizagens. Esse tipo de postura não contribui para uma relação dialógica em sala, ao contrário, visto que o professor está em posição acima de todos, enquanto os alunos estão abaixo. Nessa perspectiva, importa que os alunos obedeçam ao educador sem questionamentos, por causa de sua hierarquia. Esse autoritarismo prejudica o desenvolvimento da capacidade criadora das crianças e das outras áreas de desenvolvimento e de conhecimentos. Além desse tipo de professor, podemos citar aquele que tem atitudes passivas, ou seja, que não compreende a dimensão potente de cada ação das crianças, das curiosidades delas em relação a elas mesmas, ao outro e ao mundo. Alguns professores compreendem erroneamente o desenho infantil, a exemplo daquele educador que dá uma folha para a criança desenhar só para ocupar o tempo da 'aula'. Lowenfeld (1977) defende que esses tipos de educadores são uma influência negativa sobre a produção do desenho, além de prejudiciais à formação da personalidade infantil.

Finalizamos este tópico, ao comentar sobre a importância do protagonismo infantil, de considerar as crianças como sujeitos de direitos e deveres e que não devem ser tratadas como adultos em miniatura, mas sim como crianças que são capazes de aprender, pesquisar e explorar (LOWENFELD, 1977). Lowenfeld em 1947, data da primeira edição do livro que retratamos aqui, Desenvolvimento da capacidade criadora, que já tinha uma visão bem atualizada e moderna sobre a infância e sobre o protagonismo da aprendizagem das crianças, quando relata:

A maioria das crianças que começa a frequentar a escola se encontra na fase das primeiras tentativas de representação. Portanto, é imperativo que esse início nas experiências artísticas seja significativo. Muito do que ocorre dentro da escola é ditado pela sociedade adulta em que vivemos; contudo, como analisamos, a criança não é uma miniatura de adulto nem pensa em termos adultos. A arte pode proporcionar não só a oportunidade de desenvolvimento em muitas áreas vitais, mas, também o ensejo de a criança investigar, inventar, explorar, cometer erros, sentir medo e aversão, amor e júbilo. Por fim, e isto é essencial, a criança deve ter, por si mesma, todas essas experiências da vida, como entidade 
- como indivíduo que pode, deve e irá pensar por si mesmo (LOWENFELD, 1977, p. 178).

Devido aos nossos estudos e pesquisas, percebemos, na evolução das produções artísticas, especificamente do desenho, o incentivo às sensibilidades criadoras infantis por meio da expressão da imaginação, possibilitando que as crianças criem o final que imaginarem, o que favorece a criação e a imaginação dos desenhos. Na abordagem da cognição imaginativa de Efland, as crianças podem se expressar por meio de metáforas, representando narrativas contadas ou suas próprias experiências de narrativas. Nessas experiências criadoras, que são comuns no desenvolvimento infantil, as crianças utilizam múltiplas linguagens expressivas e articuladoras, seja no contexto em que vivem, seja na escola, por meio do contato com a natureza, dentre várias outras vivências que estimulam a criatividade infantil e que são permeadas de significados para a vida delas.

Segundo a Base Nacional Curricular Comum (2018), o documento oficial que norteia e orienta as experiências e vivências das crianças nas Instituições Escolares, para a Educação Infantil, todas essas experiências devem ser organizadas em Campos de Experiências e Direitos de Aprendizagem. Os campos de Experiências são divididos em cinco campos: CAMPO 1 - O eu, o outro e o nós; CAMPO 2 - Corpo, gesto e movimento; CAMPO 3 - Traços, sons, cores e formas; CAMPO 4 - Escuta, fala, pensamento e imaginação; CAMPO 5 - Espaços, tempos, quantidades, relações e transformações. Já os Direitos de Aprendizagem são seis: direito de conviver; direito de brincar; direito de participar; direito de explorar; direito de expressar e direito de conhecer-se.

Respeitando os atuais estudos para o desenvolvimento e para a aprendizagem na Educação Infantil, conseguimos visualizar que as experiências expressivas com as crianças na instituição escolar, ou em outro meio do seu cotidiano, podem partir da cognição imaginativa, de Efland. Como abordagem dessas vivências, a partir do uso de metáforas e experiências de narrativas como recurso, pode-se auxiliar nas experiências das crianças e favorecer oportunidades de expressão propícias à criação/criatividades; ilustrações dos processos imaginativos e vividos para materialização em produções. Ademais, por intermédio de desenhos, é possível várias análises e interpretações, podendo apresentar várias metáforas visuais. Por fim, os estudos do desenvolvimento do desenho infantil, de Lowenfeld, podem auxiliar na análise dos desenhos das crianças, permitindo entender em qual fase a criança se encontra, mas principalmente articular quais as especificidades imaginativas e criadoras se apresentam nessas etapas.

\section{A relação entre a cognição imaginativa e o desenvolvimento da capacidade criadora}

Revista Digital do LAV - Santa Maria - vol. 14, n. 2, p. 42 - 67 - mai./ago. 2021 ISSN 1983 - 7348 http://dx.doi.org/10.5902/1983734864471 
A teoria do desenvolvimento da capacidade criadora, especialmente as contribuições referentes ao desenho Infantil, de Lowenfeld (1977), favoreceu a compreensão e a investigação dos desenhos infantis. Somado a isso, serviu de base para a realização de nossos estudos, nos quais utilizamos a abordagem da cognição imaginativa, de Efland (2004), como meio de aplicação de uma aprendizagem permeada de significados para as crianças. Por meio dessa perspectiva, acreditamos que as crianças usam suas imaginações e autonomias, tornando possível a correlação entre a abordagem da cognição imaginativa e do desenvolvimento da capacidade criadora, no que concerne ao desenho infantil.

Percebemos que tais teorias podem contribuir para o desenvolvimento cognitivo afetivo e social das crianças, e favorecer que os professores estudem e atualizem seus processos de ensino e aprendizagem, permitindo que estimulem e incentivem o desenvolvimento do desenho das crianças. Além disso, poderão disponibilizar os meios e recursos necessários e possibilitar experiências e vivências significativas para estimular a imaginação e a cognição das crianças. Portanto, recomendamos o contato com experiências variadas com a natureza, com histórias, com assuntos que possam ampliar seus repertórios prévios visuais, suas imaginações, suas linguagens, seus sentidos e que evitem os estereótipos criados pela sociedade como desenhos prontos, tendo como objetivo geral, na maioria das vezes, um fim mercadológico capitalista. Somente assim as crianças se desenvolverão como ativas e críticas, tendo opiniões próprias, ou seja, poderão se tornar adultos mais sensíveis, críticos e transformadores da realidade em busca do bemestar coletivo da humanidade.

Lowenfeld (1977) retrata a importância da compreensão do processo mental infantil, o que gera uma correlação com a abordagem da cognição imaginativa de Efland (2004), pois ele considera a fantasia como característica da infância e fala sobre o processo de desenvolvimento intelectual. Em suma, este será mais alto quanto mais diversas forem as experiências. $O$ autor comenta também que quanto mais detalhes representados no desenho infantil, mais conscientizada a criança está em relação ao seu meio. Nas palavras do educador:

O desenvolvimento de conceitos em arte e de suas relações com a realidade pode ajudar-nos a compreender o processo mental infantil. Embora seja uma idade em que encontramos grande flexibilidade e variação nos desenhos, também descobriremos nela rápidas mudanças no modo de pensar. Não estamos examinando o pensamento como a silenciosa contemplação de um problema, mas, sim, como o desenvolvimento intelectual em sua totalidade, que nesta idade se encontra admiravelmente combinado com fantasia, realidade e reações biológicas ao meio.

A criança que atingiu a idade cronológica de quatro ou cinco anos,

Revista Digital do LAV - Santa Maria - vol. 14, n. 2, p. 42 - 67 - mai./ago. 2021 ISSN 1983 - 7348 
mas que ainda raciocina em função de movimentos, não avançou intelectualmente para um estágio médio de crescimento. Ao observarmos uma série de desenhos, por uma criança de cinco anos, com certeza, desejaríamos deduzir algumas tentativas de representação. Quanto mais diferenciadas forem essas experiências, mais alto será o nível alcançado pelo desenvolvimento do processo intelectual. Deste modo, quanto mais detalhes forem incluídos num desenho, mais cônscia a criança está das coisas que a cercam. Nosso conceito global de inteligência está primordialmente baseado nesse pressuposto (LOWENFELD, 1977, p. 160-161).

No mesmo sentido, Lowenfeld (1977) complementa, ao retratar a importância das experiências das crianças, que:

A motivação artística, para este grupo etário particular, concentrase nas experiências que a própria criança teve, tanto em seu eu físico como na sua fantasia, ou nas experiências que lhe foram indiretamente propiciadas. Embora sejamos uma combinação de fatores hereditários e ambientais, e muito pouco ou nada possamos fazer, a respeito da hereditariedade das crianças com quem trabalhamos, devemos concentrar-nos nos fatores ambientais, no contexto de uma situação de aprendizagem. A arte pode desempenhar papel decisivo, ao proporcionar o meio em que evoluem os vários padrões de desenvolvimento. Ela constitui a parte predominante em nosso sistema educacional, sobretudo na área da evolução perceptual, ou seja, o desenvolvimento da conscientização das coisas que nos cercam, através dos sentidos; mediante o progresso criador, logra-se o desenvolvimento das características de flexibilidade, de pensamento imaginativo, originalidade e fluência mental; e é também através do desenvolvimento emocional que se adquire a capacidade de enfrentar novas situações, de expressar tanto os sentimentos agradáveis como os penosos. Em menor grau, a arte também proporciona, nesta idade, o ensejo de evoluir nas áreas intelectual, social e estética (LOWENFELD, 1977, p. 176-178).

Pelo fato de cada criança ter sua personalidade e individualidade, consequentemente cada uma tem um desenho caracterizado por uma simbologia representativa, marcada por suas experiências, suas imaginações, suas características de personalidade e desenvolvimento. Entendemos que cada desenho de criança é único e representativo, a partir do qual é possível fazer várias interpretações e análises de como estão os desenvolvimentos das crianças.

O entrelaçamento entre as teorias dos dois autores possibilitou uma comparação entre suas contribuições para o desenvolvimento cognitivo infantil, utilizando a área das artes como possibilidade de estudo e de investigação por meio das criações, da expressão com liberdade, favorecendo o desenvolvimento de estudos, em que analisamos e visualizamos que as crianças podem usar sua autonomia e imaginação para registrarem e criarem o que é importante para elas, ou seja, o que é significativo com base em suas próprias experiências. 
Percebemos que as contribuições teóricas de Lowenfeld (1977) são voltadas para orientar tanto os pais, quanto os educadores, a auxiliar e possibilitar o desenvolvimento da capacidade criadora das crianças. Consideramos de extrema importância suas contribuições, também, por ser em uma linguagem de fácil compreensão, possibilitando que suas orientações sejam entendidas também pelos pais que podem estimular, em casa, as crianças no seu processo criador.

Lowenfeld (1977) tem um estudo mais focalizado e aprofundado nas características e especificidades das crianças e nos seus desenvolvimentos específicos, relacionados, principalmente, ao desenho infantil, em que ele cita em cada desenvolvimento a importância das Artes. Como já foi retratado neste artigo, o educador também fez uma teoria do desenvolvimento do desenho infantil, dividindo em fases etárias - teoria que permite a análise dos desenhos infantis com mais embasamento, isto é, possibilita uma fundamentação teórica mais prática e voltada às observações e análises dos desenhos das crianças que podem ser criados com a abordagem da cognição imaginativa de Efland (2004).

Efland (2004), ao incluir todas as idades e públicos (crianças, adolescentes e adultos), relata que não há idade mínima ou máxima para desenvolver a imaginação e a criação nas Artes, como podemos visualizar no dia a dia nas Instituições Escolares. Essas observações, em relação ao desenvolvimento infantil por meio das Artes, foram um dos principais incentivos para a determinação da escolha do tema deste artigo, em que consideramos o processo de criação infantil rico em significados das suas próprias experiências do seu cotidiano, seja na escola ou nos contexto em que vivem, como em casa, focando o desenho infantil criativo e aberto à liberdade, à autonomia e à representação da imaginação, dificultando produções artísticas estereotipadas e padronizadas, bem como permitindo que as crianças possam ter contato com diferentes materiais expressivos.

Outra diferença entre os dois é que Efland (2004) fez um estudo bem mais aprofundado sobre a natureza cognitiva da imaginação e organizou tópicos refletidos e estudados pela abordagem que criou, divididos em Categorização, Imagens-Esquemas, Metáforas e Estrutura de Narrativas. Nessa pesquisa bibliográfica deste artigo, voltada para o estudo da abordagem da cognição imaginativa na Educação Infantil, estudamos, pesquisamos e fizemos um recorte, focalizando dois desses tópicos, quais sejam: a metáfora e as estruturas de narrativas. Por intermédio dos estudos desta abordagem, percebemos que ela, também, pode ser aplicada como metodologia das experiências que são favorecidas para as crianças, permitindo que elas criem desenhos baseados nas suas imaginações, criatividades e no contexto de vida e realidade em que estão inseridas. 
A abordagem da cognição imaginativa e a teoria do desenvolvimento da capacidade criadora infantil: relações teóricas entre Efland e Lowenfeld acerca do processo de construção do desenho infantil

Lowenfeld (1977) tem um enfoque mais pedagógico e menos aprofundado em relação à imaginação, considerando-a como forma de expressar a criatividade, com o objetivo principal de incitar os adultos que convivem com as crianças (pais e professores) a incentivarem o desenvolvimento da capacidade criadora. Assim, o autor se refere a uma imaginação mais voltada aos processos de desenvolvimento da capacidade criadora da criança, focado no desenho infantil, que generaliza a imaginação como estímulo e como forma da criança expressar sua criatividade. Além disso, o educador tece críticas, como podemos conferir na citação abaixo, às ações errôneas dos adultos que, em vez de estimular as crianças, estereotipam a aprendizagem em um padrão que não abre espaço para a criatividade e para a imaginação:

Diz-se, por vezes, que a escola pública desencoraja o pensamento criador, mas é que ela tem muitas tarefas a seu cargo, e talvez haja maior justificação em dizer que o pensamento criador não ocupa posição muito elevada na lista dos objetivos da maioria dos professores. Algumas provas indicam que estes não gostam da criança criadora (Getzels e Jackson, 1962). Há motivos para crer que o aluno dócil e conformista é recompensado na escola, em restrição ao desenvolvimento da imaginação e do pensamento criador. Isto também pode acontecer nas aulas de arte. À influência da família é um fator significativo para estimular o desenvolvimento da capacidade criadora (Weisberg e Springer, 1967), mas a sociedade, através dos pais, professores ou companheiros da mesma idade, certamente recompensa certos tipos de condutas em determinadas épocas e talvez, por isso, o comportamento criador se desenvolve segundo um padrão tão irregular (LOWENFELD, 1977, p. 66).

Infelizmente, o que acontecia há muitos anos, ainda ocorre em práticas educativas voltadas a recompensar os alunos dóceis e conformistas, pois alguns educadores acham que as crianças devem ser obedientes e fazer as coisas exatamente como mandam, sem barulho ou bagunça, tampouco sem falar e expor suas opiniões. Já as crianças que querem experimentar, bem como expressar sua autonomia e imaginação são rotuladas como difíceis e, muitas vezes, são 'castradas' nos seus processos criativos na escola ou em casa.

Nós, como pesquisadores e estudantes, concordamos com uma metodologia que critica e que tenta mudar práticas errôneas nas Instituições Escolares, responsáveis por prejudicar o desenvolvimento do processo criativo das crianças, voltadas a um ensino tradicional e verticalizado, nas quais o professor é o centro do processo de ensino e aprendizagem e está em posição superior a seus alunos, dando lugar ao autoritarismo em sala, onde somente tem importância a 'voz' do professor. Na verdade, as crianças são o centro do processo de ensino e aprendizagem, portanto, deve ser dado ' $v o z^{\prime}$ e protagonismo a elas e, consequentemente, a liberdade e a autonomia de gerirem o que é mais importante e significativo para elas. Nesse sentido, o educador deve estar inserido 
no processo de ensino e aprendizagem, dando ênfase a um ensino 'horizontal', permitindo o diálogo e o respeito à opinião de todos, assim como Paulo Freire relata em seu livro Pedagogia da Autonomia: saberes necessários à prática educativa.

Entendemos que os educadores devem observar, analisar e intervir, quando necessário, e estimular o desenvolvimento do processo criativo infantil. As crianças, por sua vez, devem ser as protagonistas das suas criações por intermédio de experiências significativas em que devem vivenciar e brincar, com o desenho, utilizando narrativas e metáforas faladas e visuais. A partir desses recursos, há uma ampliação de significados e, consequentemente, o favorecimento da imaginação, da autonomia e do desenvolvimento da criação infantil.

Efland (2004) explica que o conceito de imaginação, em um enfoque cognitivo, é a forma de criar imagens mentais de coisas que não estão ao alcance dos nossos sentidos, conforme explicitado pelo trecho abaixo:

La imaginación es la acción o el poder de formar imágenes mentales de lo que no está realmente presente para nuestros sentidos o lo que no se ha experimentado. También es la acción o poder de crear nuevas ideas o imágenes a través de la combinación y reorganización de experiencias previas. Este último poder «a menudo se considera la facultad más seria y profundamente creativa que percibe las semejanzas básicas entre cosas, en oposicióna la fantasía, la facultad más ligera y decorativa que percibe las semejanzas superficiales» (Websters New World Dictionary, College Edition, 1964, p. 725). Esta definición de dicionário ilustra el legado de problemas de valores asociados com la cuestión. Tenemos una tendencia a rechazar o descartar ideas si existen «sólo en la imaginación», y a desconfiar de los individuos que tienen una «imaginación hiperactiva». El escepticismo cartesiano se expresa en la articulación de tales sentimientos (EFLAND, 2004, p. 183).

Efland, na citação acima, critica a tendência que temos de rejeitar ideias que tem como base a imaginação - isso acontece há muitos anos e ainda persiste nos dias atuais. Ainda persiste, também, a dicotomia da razão versus emoção na sociedade, com uma série de preconceitos. Esta pesquisa bibliográfica entrou nesse embate, pois como retrata a abordagem da Cognição Imaginativa, demos um enfoque que deu importância a uma metodologia que retratou a imaginação como um caminho para o desenvolvimento da cognição nas Artes das crianças. Buscamos estudos e meios de comprovar a relevância da imaginação nas Artes para o desenvolvimento da capacidade criadora das crianças, focando o desenho infantil como recurso de autonomia e liberdade de representação da imaginação infantil, e de desenvolvimento artístico por meio das experiências vivenciadas, metáforas e experiências de narrativas. Os adultos podem e devem apresentar e oportunizar que as crianças vivenciem de forma lúdica e significativa seus próprios processos de ensino e aprendizagem. Nesse sentido, as Artes são um excelente recurso 
A abordagem da cognição imaginativa e a teoria do desenvolvimento da capacidade criadora infantil: relações teóricas entre Efland e Lowenfeld acerca do processo de construção do desenho infantil

para desenvolver o processo criador das crianças, respeitando suas autonomias e imaginações.

A diferença entre a abordagem de Efland e de Lowenfeld segue, pois enquanto Efland desenvolve um estudo científico sobre o lugar da imaginação nos estudos cognitivos referente às Artes, Lowenfeld construiu e apontou orientações a adultos de como incentivar o desenvolvimento da capacidade criadora das crianças, como nos desenhos infantis. Abaixo, Lowenfeld continua esses incentivos, propondo e explicando a importância de um lugar especial para favorecer a criatividade:

A criatividade necessita ser alimentada por um tipo especial de ambiente. A atmosfera de 'vale-tudo' parece exercer uma influência tão negativa quanto o meio autoritário, onde os indivíduos estão completamente dominados. A criatividade deve ser amparada, mas, ao mesmo tempo, precisa ser orientada para caminhos socialmente aceitáveis. Considerou-se a curiosidade como um dos impulsos primários (Fowler, 1965), mas forças poderosas podem estar atuando contra a criatividade em muitas escolas públicas. As experiências artísticas proporcionam uma excelente oportunidade para reforçar o pensamento criador e propiciar os meios pelos quais os jovens podem desenvolver suas representações imaginativas e originais sem censura. Não há dúvida de que uma certa dose de ansiedade é produzida nas crianças que temem confiar em seu próprio discernimento, mas a arte é um bom método para libertarIhes a imaginação (LOWENFELD, 1977, p. 66, grifo no original).

Tanto o enfoque mais científico dos estudos sobre a cognição imaginativa, de Efland, quanto os estudos mais práticos de Lowenfeld, com a intenção de orientar pais e professores em relação ao desenvolvimento do desenho infantil, são relevantes para o desenvolvimento do presente artigo. Entretanto, a abordagem da Cognição Imaginativa, de Efland, é bastante relevante, porque pode ser aplicada como metodologia que favorece o desenvolvimento cognitivo, afetivo e social das crianças nos seus próprios processos criadores. Já o desenvolvimento da capacidade criadora, focando o desenvolvimento do desenho infantil, dá uma boa base para entender e analisar os desenhos das crianças e as situações vivenciadas das experiências em sala de aula que propiciam a criação infantil, especificando o desenho, como os materiais, ambientes propícios, estímulos e incentivos, intervenções do educador, vivências significativas para o desenvolvimento artístico das crianças, dentre outras.

Efland (2004), em uma abordagem mais científica do que Lowenfeld, colabora para a imaginação ter espaço nos estudos cognitivos. No excerto a seguir, Efland faz referência aos estudos de Lakoff e Johnson sobre o pensamento cotidiano e a relação com a metáfora para significar esse pensamento:

Además, Lakoff y Johnson (1980) observaron y documentaron el hecho de que «las categorías de nuestro pensamiento cotidiano son

Revista Digital do LAV - Santa Maria - vol. 14, n. 2, p. 42 - 67 - mai./ago. 2021 ISSN 1983 - 7348 
ampliamente metafóricas y que nuestro razonamiento cotidiano supone implicaciones e interferencias metafóricas. Como consecuencia, la racionalidad ordinaria es imaginativa por su propia naturaleza» (p. 193). Añaden: La metáfora es una de nuestras herramientas más importantes para intentar comprender parcialmente lo que no puede comprenderse totalmente: nuestros sentimientos, las experiencias estéticas, las prácticas morales, y la conciencia espiritual. Estos esfuerzos de la imaginación no están faltos de racionalidad; puesto que usan la metáfora, utilizan una racionalidad imaginativa (EFLAND, 2004, p. 194).

Esse enfoque cognitivo de Efland também é muito importante para dar visibilidade acadêmica a estudos com enfoque mais imaginativo nas Artes, possibilitando estudos em todas as etapas da Educação, desde a Educação Básica à Superior. Esta pesquisa estudou uma pequena parcela que é a Educação Infantil, mas com uma enorme importância devido ao fato de ser a primeira etapa da Educação Básica. Nessa etapa, deve-se dar importância ao desenvolvimento infantil e oferecer oportunidades para as próprias crianças serem protagonistas dos seus processos de aprendizagem. Assim, ao desenvolverem suas próprias opiniões e críticas, podem ter uma boa base de aprendizagem e desenvolvimento nas etapas seguintes de estudos, além de se formarem como seres independentes, críticos, com opiniões próprias e altamente capazes de interpretar o mundo e de intervir positivamente na sociedade.

Com essas citações acima de Efland, referimo-nos às experiências de que as crianças podem experimentar e vivenciar, via abordagem da cognição imaginativa, situações e brincadeiras a trabalharem a imaginação por meio de metáforas e experiências de narrativas, possibilitando a expressão e o registro dessas experiências no desenho, por exemplo.

Para la mayoría de la gente, el término imaginación «connota creatividad artística, fantasía, descubrimiento científico, invención y novedad» (Johnson, 1987, p. 139), y tiene poco - o nada - que ver con el mundo cotidiano. Estas creencias son secuelas del romanticismo del siglo XIX. Johnson quería explicar cómo las imágenes esquemas que surgen en la experiencia corporal y perceptiva dan lugar a operaciones imaginativas como la metáfora y la narrativa. Es más, estos procesos operan a través de toda la gama de la cognición humana, desde las transacciones diarias de la vida ordinaria, hasta la conceptualización abstracta en el nivel más elevado. Johnson estaba resuelto a demostrar que estas operaciones tienen lugar en el habla cotidiana, en el lenguaje de los científicos, y en las artes. Y para dar apoyo a la idea de que la metáfora y la imaginación impregnan toda la gama de la cognición humana, pospuso intencionalmente toda discusión acerca de las artes hasta que quedara claro el punto principal de su argumentación: que las operaciones cognitivas imaginativas como la metáfora emergen en el punto más alto del espectro de la actuación cognitiva humana. Como ya hemos sefialado antes, Kant (1790/1964) creía que la imaginación ponelas ideas intelectuales en

Revista Digital do LAV - Santa Maria - vol. 14, n. 2, p. 42 - 67 - mai./ago. 2021 ISSN 1983 - 7348 http://dx.doi.org/10.5902/1983734864471 
movimiento, «avivando así la mente al abrirla a la perspectiva de un campo ilimitable de representaciones gemelas» (p. 318). (EFLAND, 2004, p. 206).

Lowenfeld não focava a experiência da vida cotidiana tão profundamente como Efland, que referencia a fala de Jonhson, o qual explicava que a imaginação e o surgimento das metáforas fazem parte da cognição humana e surgem por meio de experiências corporais e perceptivas, resultando em operações ligadas à imaginação. Nessa perspectiva, a metáfora e as narrativas ocorrem, muitas vezes, nas experiências da vida cotidiana e no contexto em que cada um vive, dando um significado de vivência e importância a elas. As crianças, muitas vezes, representam em seus desenhos as suas experiências do seu cotidiano, onde retratam o que é importante e significativo para elas naquele momento.

Efland (2004) explica que a utilização da imaginação e o papel que ela pode desempenhar na criação de sentido pessoal e na transmissão da cultura tornam-se a razão de ser e o objetivo principal da introdução da Arte na educação. Esse papel da imaginação das Artes na educação, quanto mais cedo começar, melhor para o desenvolvimento cognitivo e para a formação do senso crítico do ser humano. De fato, essa é uma das razões desta pesquisa focalizar a Educação Infantil, pois acreditamos no potencial das crianças - seres altamente capazes e criativos que possuem competência de abstrair e assimilar muitos conceitos e conhecimentos. As Artes, portanto, tem um 'lugar' especial nessas aprendizagens - essa afirmação deriva das nossas experiências em sala com a Educação Infantil, em que constatamos o desenvolvimento de várias expressões artísticas, principalmente nos desenhos. Essa última afirmação pode ser visualizada com experiências de narrativas e metáforas no processo de ensino e aprendizagem das crianças e pode possibilitar que o adulto responsável favoreça situações de aprendizagem onde as crianças possam desenhar com essa abordagem da Cognição imaginativa. Efland continua a dar importância a imaginação nas Artes em um enfoque mais imaginativo, diferentemente de Lowenfeld:

Permítanme que haga hincapié de nuevo sobre este punto; las artes son lugares en que las construcciones de la metáfora pueden y deben convertirse en el objeto principal de estudio, en que es necesario compreender que las imágenes visuales o las expresiones verbales no son hechos literales, sino que son representaciones de significados que pueden observarse bajo otra luz. Sólo en las artes los procesos y los productos de la imaginación se encuentran y exploran con plena conciencia; se convierten en objetos de investigación, a diferencia de las ciencias donde las metáforas que se usan quedan ocultas (EFLAND, 2004, p. 207).

Efland fala da importância da metáfora como meio para representar a imaginação e como forma de compreender e representar o mundo à sua volta, principal objetivo 
educativo das Artes. Entendemos que a metáfora é uma ferramenta e meio para representar a imaginação, além de uma forma mais ampliada e abrangente de compreender e representar o mundo. Por meio dela, muitas vezes, tornamos 'entendível' o que não conseguimos expressar com as palavras comuns presentes em nossa linguagem. Possibilitar às crianças experiências significativas que favoreçam um processo de aprendizagem envolvido com metáforas e imaginação, no nosso ponto de vista, é ampliar a aprendizagem e o desenvolvimento cognitivo das crianças, dando espaço para um processo criador que amplia a representação de mundo que elas têm.

Hacer que los estudiantes comprendan lo imaginativo en cuanto recursos ornamentales como la metáfora, usados principalmente por artistas y poetas, es de importancia secundaria. Me inclino más hacia actividades en que el estudiante alcance una comprensión del mundo al que hacen referencia las obras de arte, y del papel que el artista tiene en la representación de este mundo. Es más, una educación artística que no consiga reconocer el carácter metafórico de los significados en las artes no tiene un objetivo educativo serio (EFLAND, 2004, p. 207).

Percebemos que as duas teorias influenciam positivamente no desenvolvimento do desenho infantil. Lowenfeld tem uma teoria baseada em recomendações, sugestões para educadores e pais, e mostra vários exemplos de desenhos das crianças em cada fase que é atribuída na sua teoria. Já na abordagem de Efland, a aprendizagem tem um teor mais imaginativo e cognitivo nas Artes, ressaltando ferramentas como metáfora e experiências de narrativas que podem ser utilizadas em todas as etapas da Educação, incluindo a Educação Infantil.

\section{Considerações finais}

É muito relevante possibilitar o processo de construção do desenho infantil, para a área das Artes, da Educação e para os estudos dos desenvolvimentos da primeira infância, focando o processo criador e artístico das crianças e dando visibilidade às crianças nas Artes. Além disso, para desmistificar falácias que ainda existem a respeito da área, a exemplo daquelas que pregam que, por exemplo, um desenho serve apenas para ensinar as crianças a terem coordenação motora nas mãos e a facilitar o processo de escrita, ou que as artes servem somente para ocupar o tempo. Reconhecemos que as Artes precisam ser trabalhadas como fim, com seus objetivos e suas especificidades desde a Educação Infantil, pois as crianças são muito capazes de desenvolverem seus processos criadores em consonância com seus desenvolvimentos cognitivos, afetivos e sociais.

Como já foi abordado antes, voltamos a afirmar a importância da Educação Infantil para a área das Artes, pois ela é a primeira etapa da Educação básica, tornando-se a base 
A abordagem da cognição imaginativa e a teoria do desenvolvimento da capacidade criadora infantil: relações teóricas entre Efland e Lowenfeld acerca do processo de construção do desenho infantil

inicial do processo de ensino e aprendizagem. Portanto, explanar e trabalhar as Artes, nessa etapa, é essencial para formar e desenvolver seres criativos, autônomos, independentes, pensantes e críticos, que têm suas próprias opiniões sobre o mundo e sobre seu próprio processo criador, como exemplo o desenho. As crianças têm a seu favor a ludicidade, desde a sua natureza infantil, pois aprendem brincando e criam dentro desse contexto de brincadeiras, de divertimento e prazer. Nesse processo lúdico, utilizam muito a imaginação e suas experiências significativas dos contextos em que vivem, favorecendo seus próprios desenvolvimentos cognitivo, social e afetivo. Portanto, o desenho é um excelente exemplo que oportuniza esses desenvolvimentos por meio das Artes, respeitando o desenvolvimento do processo criador infantil.

Relatamos que buscamos ampliar nossos estudos e conhecimentos sobre o desenvolvimento cognitivo das crianças por intermédio das suas expressões artísticas, estudando a abordagem da cognição imaginativa como metodologia que pode ser aplicada por meio de experiências que favoreçam a ampliação e o trabalho com a imaginação, utilizando metáforas e experiências de narrativas. Assim, visualizamos que é possível favorecer a construção de conhecimentos do mundo, de si e do outro, através de experiências e de contações de histórias que também possibilitem a construção e ampliação da imaginação das crianças, onde as mesmas podem ter a oportunidade de expressarem e desenvolverem suas criatividades e autonomias, usando suas imaginações, iniciativas e autonomias nas suas produções, como nos desenhos. Os desenhos infantis podem ser analisados e interpretados com base na teoria do desenvolvimento da capacidade criadora e podem ocorrer o surgimento de metáforas visuais e faladas e experiências de narrativas da abordagem da cognição imaginativa de Efland, sendo possível a aplicação de experiências e vivências que estimularão o surgimento deste viés metafórico e as experiências de narrativas que tenham significado para os seus autores.

\section{Referências}

BRASIL. Base Nacional Comum Curricular. Brasília: MEC, 2018. Disponível em: $<$ http://basenacionalcomum.mec.gov.br/images/BNCC_EI_EF_110518_versaofinal_site.p df>. Acesso em: 10 fev. 2021.

EFLAND, A. D. Arte y cognición: la integración de las artes en el currículum. Barcelona: Octaedro EUB (Ediciones Universitarias de Barcelona), [2002] 2004.

FREIRE, P. Pedagogia da Autonomia: saberes necessários à prática educativa. 25. ed. São Paulo: Paz e Terra, 1996.

LOWENFELD, V.; BRITTAIN, W. L. Desenvolvimento da capacidade criadora. São Paulo: Mestre Jou, [1947] 1977.

Revista Digital do LAV - Santa Maria - vol. 14, n. 2, p. 42 - 67 - mai./ago. 2021 ISSN 1983 - 7348 http://dx.doi.org/10.5902/1983734864471 


\begin{abstract}
' Atualmente é mestranda em artes na linha de pesquisa ensino e aprendizagem do Instituto Federal de Educação, Ciência e Tecnologia do Ceará - IFCE/PPGARTES. Especialista em Psicopedagogia Clínica, Hospitalar e Institucional (2017). Graduada em Pedagogia pela Universidade Estadual do Ceará (2012). Atualmente é professora da Secretaria Municipal de Educação de Fortaleza.

ii Doutor em Artes pela Escola de Belas Artes da Universidade Federal de Minas Gerais. Mestre em Informática Educativa (UFC). Licenciado em Educação Artística - Licenciatura Plena (UFRN). Professor Titular do Departamento de /IFCE dos referidos cursos: Licenciatura em Artes Visuais, Mestrado profissional em Artes. Atua também no Mestrado PROFARTES-UFC. Representa a Associação Nacional de Pesquisadores em Artes Plásticas (ANPAP) no Ceará. Avaliador do PNLD/2015-ARTE, PNLD/2018 e coordenador Pedagógico do PNLD/2019-ARTE; e líder do Grupo de Pesquisa Arte UM/CNPQ-IFCE.
\end{abstract}

Como citar esse artigo:

SOUZA, Kécia Maria Alencar; LIMA, José Maximiano Arruda Ximenes. A abordagem da cognição imaginativa e a teoria do desenvolvimento da capacidade criadora infantil: relações teóricas entre Efland e Lowenfeld acerca do processo de construção do desenho infantil. Revista Digital do LAV, Santa Maria: UFSM, v. 14, n. 2, p. 42-67, mai./ago. 2021. 